\title{
Bromelain: Methods of Extraction, Purification and Therapeutic Applications
}

\author{
Zoya Manzoor ${ }^{1}$, Ali Nawaz ${ }^{1 *}$, Hamid Mukhtar ${ }^{1}$, Ikram Haq ${ }^{1}$. \\ ${ }^{1}$ Institute of Industrial Biotechnology GC University Lahore, Pakistan.
}

\begin{abstract}
Bromelain is a concoction of sulfhydryl proteolytic enzymes. Depending upon the site of extraction it can be regarded as either stem bromelain (SBM) (EC 3.4.22.32) or fruit bromelain (FBM) (EC 3.4.22.33). Bromelain remain enzymatic active over a broad spectrumand endure a range of $\mathrm{pH}\left(5.5\right.$ to 8.0) and temperature $\left(35.5\right.$ to $\left.71{ }^{\circ} \mathrm{C}\right)$. It is one of the extensively investigated proteolytic enzyme owing to its astonishing applications in various industries. This necessitated employing a strategy that result in highest purified bromelain in less steps and lowest cost. Use of modernistic approach such as membrane filtration, reverse micellar systems, aqueous two phase extraction and chromatographic techniques have shown promise in this regard. Besides its industrial applications, bromelain has been widely utilized as a potential phytomedical compound. Some of its reported actions include inhibition of platelet aggregation, anti-edematous, anti-thrombotic, anti-inflammatory, modulation of cytokines and immunity, skin debridement and fibrinolytic activity. It also assist digestion, enhance absorption of other drugs and is a potential postoperatively agent that promote wound healing and reduce postsurgical discomfort and swelling.
\end{abstract}

Key words: Phytomedical, Anti-edematous, Fibrinolytic, Anti-thrombotic.

*Authors for correspondence: alinawazgcu@yahoo.com 


\section{INTRODUCTION}

Bromelain is a chief protease enzymes found in pineapple plant (Ananascomosus) (Smith-Marshall and Golden 2012). It has been known chemically since 1876 (Tochi et al. 2008) and was identified for the first time by Marcano in 1891 (Upadhyay et al. 2010). The investigation and isolation of bromelain has been started since 1894 (Neta et al. 2012). Sulfhydryl proteolytic enzymes are the chief constituents of bromelain (Tochi et al.2008; Gautam et al. 2010). Bromelain is abundant in stem and fruit of pineapple plant and it can also be isolated in small amount from pineapple waste such as core, leaves, peel etc. (Hossain et al. 2015). Bromelain present in fruit of pineapple has assigned the EC number EC 3.4.22.33 and is regarded as fruit bromelain (FBM). Likewise bromelain present in the stem of pineapple is called stem bromelain (SBM) and its EC number is EC 3.4.22.32. Stem bromelain possess different biochemical properties and composition as compared to fruit bromelain (Pavan et al. 2012) and contains a variegated blend of different thiol-endopeptidases. Efforts are being made by researchers to achieve highly purified bromelain in less steps and low cost. Modern strategies, such as membrane filtration (Lopes et al. 2009), reverse micellar systems (Upadhyay et al. 2010; Kumar et al. 2011), aqueous two phase extraction (Coelho et al. 2013; Novaeset al. 2013) and chromatographic techniques (Yin et al. 2011) have shown promise in this regard. Pineapple plant also contains minor quantities of other proteinases like ananain and comosain (Nadzirah et al. 2013) but bromelain is regarded as a primary and extensively investigated component (Amini et al. 2016). The reason of being such valuable is due to its miraculous utilization as phytomedical compound (Larocca et al. 2010). Bromelain displays antiedematous, fibrinolytic, anticancer, antiinflammatory, antibiotic, anticoagulative and antithrombotic functions (Kavitha et al. 2013). It is also a potential postoperatively agent that assists healing and decrease post surgical discomfort and swelling (Graf 2000). Besides clinical approach, bromelain has also employed in various industries including food industries (Maurer 2001), such as breweries (Soares et al. 2012) and flesh processing and tenderization, textile and cosmetic industries (Babu et al. 2008; Ketnawal et al. 2009). With the advent of recombinant DNA technology, scientists and researchers across the globe have been working on recombinant bromelain to achieve exaggerate and novel applications in future (Arshad et al. 2014).

\section{PROPERTIES}

Bromelain is actually a group of sulfhydryl proteolytic enzymes (Smith-Marshall and Golden 2012) and encompasses variety of cysteine proteases (Tochi et al. 2008) when extracted from the stem and fruit of pineapple plant (Neta et al. 2012; Pillai et al. 2013). Stem bromelain and fruit bromelain are both single-chain glycosylated enzymes but they possess different characteristics (Barrett et al. 2004). SBM has reduced proteolytic activity and exhibit low specificity for peptide bonds then FBM. Researchers have reported several distinct $\mathrm{pH}$ and temperature optima for the activity of bromelain towards its substrates (De Lencastre et al. 2016). The reported optimum $\mathrm{pH}$ range for SBM by various researchers is 6-7 and its optimum temperature range is $50-60{ }^{\circ} \mathrm{C}$ (Harrachi et al. 1998; Gautam et al. 2010; Xue et al. 2010). While the optimum pH range for FBM is 3-8 and optimum temperature ranges from $37-70{ }^{\circ} \mathrm{C}$ (Lopes et al. 2009; Jutamongkon and Charoenrein 2010; Silvestre et al. 2012). Likewise, the molecular weight range for SBM is $26-37 \mathrm{kDa}$ (Grzonka et al. 2007; Kumar et al. 2011) and for FBM molecular weight range is $24.5-32 \mathrm{kDa}$ (Grzonka et al. 2007; Lopes et al. 2009; Gautam et al. 2010). When bromelain is kept at $-20{ }^{\circ} \mathrm{C}$ its stability remains intact for a defined time period (Rowan et al. 1990). Amongst other, cysteine is the most efficient compound for the activation of bromelain (Grzonka et al. 2007). SBM is in fact a combination of several thiol endopeptidases (Pavan et al. 2012) and also contains compounds like peroxidases, acid phosphatase, several protease inhibitors glucosidases, cellulases, glycoproteins, carbohydrates and organically intact $\mathrm{Ca}^{2+}$ (Maurer 2001; Smith-Marshall and Golden 2012).

\section{EXTRACTION AND PURIFICATION METHODS}

Besides its clinical applications bromelain has been subjected to many other industries due to its enormous benefits. Researchers thereby are trying various conventional as well as latest purification techniques to achieve bromelain in highest purified form at reduced cost (Arshad et al. 2014). As compared to fruit, bromelain concentration is high in stem and is thus a cheaply available source of bromelain (Tochi et al. 2008). Other parts of pineapple are also investigated for the presence of bromelain (Ketnawa et al. 2012) including peel, core 
and crown etc. Extraction of bromelain from these parts is attractive not only from environmental point of view but also economically (Novaes et al. 2013). Bromelain can be easily extracted from the juice of pineapple by ultrafiltration (Larocca et al. 2010) but still FBM is not commercially available due to being different from SBM (Pavan et al. 2012). The marketable bromelain is mostly extracted from the stem of pineapple through centrifugation, ultrafiltration, lyophilization (Corzo et al. 2011) and two-step Fast Protein Liquid Chromatography (FPLC) (Harrach et al. 1998). Once extracted, the crude mixture containing required enzyme is then exposed to numerous purification stages to eradicate impurities that may interfere with bromelain to hinder its application and reduce the specific activity of the enzyme (Illanes 2008). Product purity is the key factor which may constitute a large proportion of the total enzyme production cost (Lightfoot 1990). Several conventional isolation and purification techniques are now obsoleted because of their low purification potential (Soares et al. 2012).So the extraction and purification strategy (Figure 1) designed should be selective for the desired product, cheap, high yielding and speedy (Gupta et al. 2004).

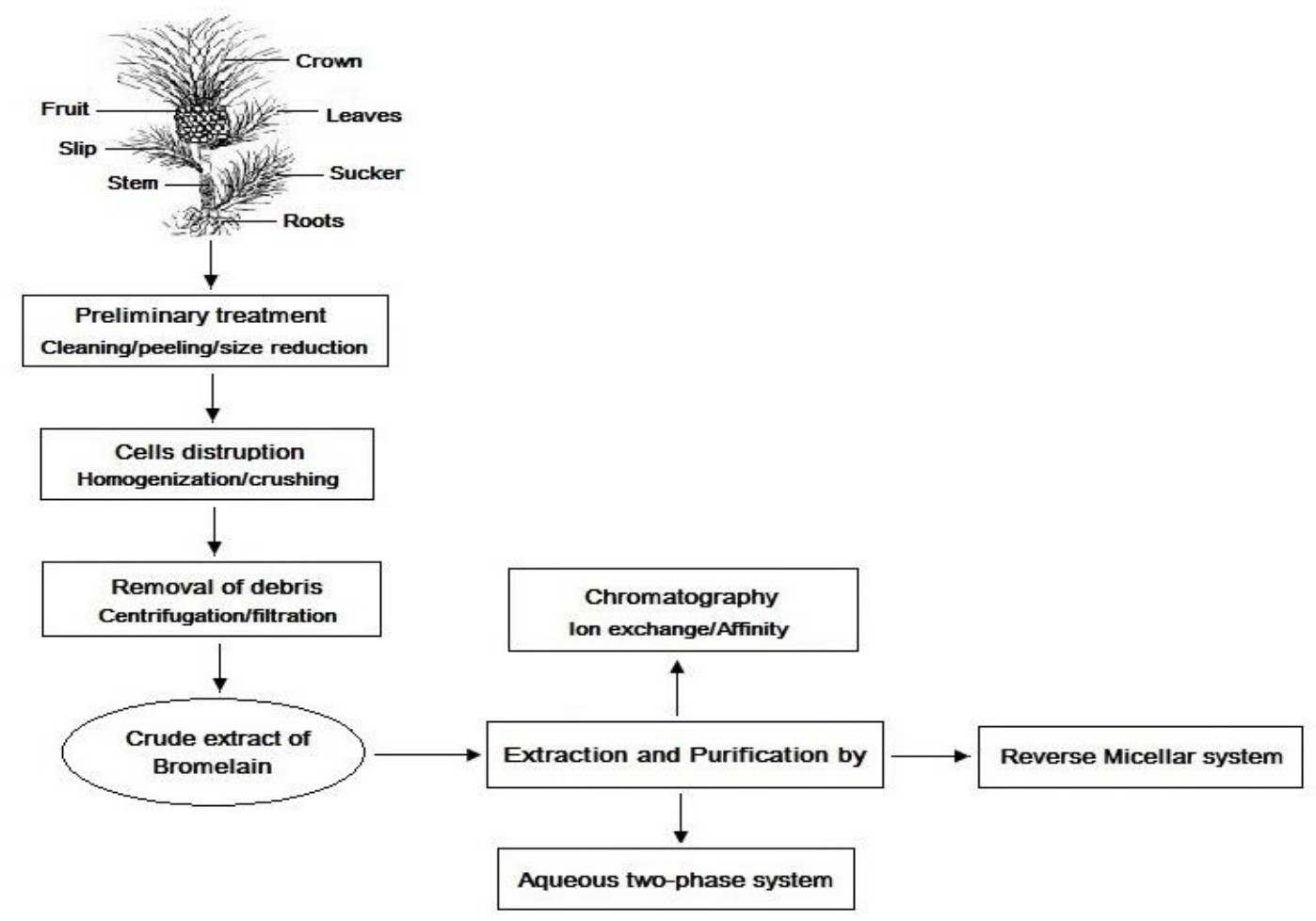

Figure 1 - Overview of extraction and purification of Bromelain.

Due to increased interest of scientists toward bromelain, several new purification techniques have been employed for its extraction and purification (Table no. 1). These include:

1) Aqueous two phase systems (Babu et al. 2008; Ferreira et al. 2011; Coelho et al. 2013; Spir et al. 2015).

2) Membrane processes (Doko et al. 2005; Lopes et al. 2009)

3) Precipitation (Doko et al. 2005; Devakate et al. 2009; Soares et al. 2012).

4) Reversed micellar systems (Hemavathi et al. 2007; Navapara et al. 2008; Kumar et al. 2011).
5) Different chromatographic techniques (Devakate et al. 2009; Li et al. 2009; Paulo et al. 2012).

\section{Reverse micellar system}

Micelle is an aggregate of molecules possessing both polar and non-polar regions. Reverse micelles are thermodynamically stable, minute surfactants that hold water in their interior surrounded by organic phase (Andray et al. 2001). Only protein of interest is entrapped in micelle (Figure 2) whereas other impurities remain in organic phase (Lee and Chong 2011). Reverse micellar system is an encouraging strategy for downstream processing. It is ideal to 
extract biomolecules through diluted samples. Reverse micellar system possess higher sample loading capacity, are specific and easy to operate (Chen et al. 2008).

RMS are also being used for the extraction and purification of bromelain from ananas stem and waste. Pineapple core yielded $106 \%$ active recovery and 5.2 purification fold (Hebbar et al. 2008). There is also reported use of RMS for extraction of bromelain from pineapple where it yielded $97.56 \%$ activity recovery and 4.54 purification fold (Hemavathi et al. 2011). Researchers are implementing various modifications in RMS to upgrade the yield and purification fold. To purify bromelain at larger scale, scale-up studies by phase transfer mode of reverse micellar system are also performed which yielded purification fold of 2.43 with an activity recovery of $81.3 \%$ (Hebbar et al. 2011). To uplift the efficacy of process RMS coupled with ultrafiltration was also studied which resulted in an activity recovery of $95.8 \%$ and purification factor after ultrafiltration of 8.9-fold (Hebbar et al. 2012). The use of affinity based reverse micellar extraction and separation technique to extract and purify bromelain from pineapple waste yielded purification of 12.32 fold with an activity recovery of $185.6 \%$ (Kumar et al. 2011). Moreover the process optimization studies for RMS had been reported (Fileti et al. 2009; Dhaneshwar 2014) and both the batch and continuous extraction of bromelain from pineapple juice by under optimized conditions was also studied (Fileti et al. 2007). A neutral model developed for bromelain extraction from pineapple juice by RMS under optimized conditions gave 4.96 purification factor with productivity of $1.29 \mathrm{ml} / \mathrm{min}$ (Fileti et al. 2009).

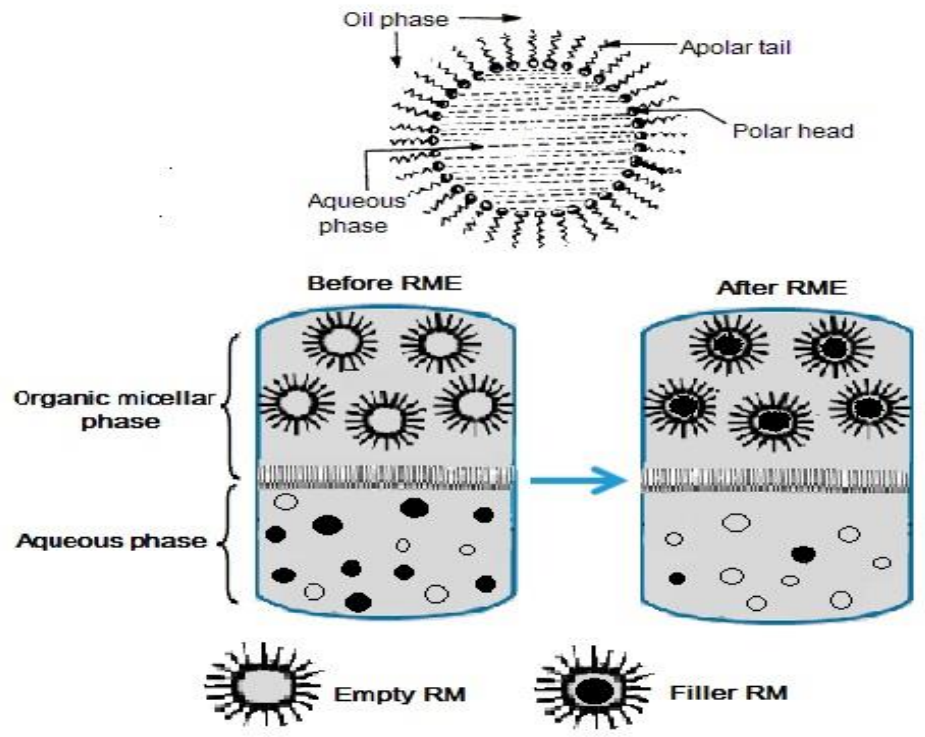

Figure 2 - Stages in working of Reverse Micellar System (RMS).

\section{Aqueous two phase system (ATPS)}

The aqueous two-phase systems consists of a polymer and a salt (or two polymers) and have been regarded as extensively used tools for extraction and purification of biomolecules (Rabelo et al. 2004). It is low cost, rapid, possess reusable polymers (Johansson et al. 2011), scalable (Asenjo and Andrews 2011) and can withstand high biomass load as compared to rest of the separation systems (Kaul 2001). ATPS is reported as a challenging technique for the separation of molecules that are hard to be separated through other methods and preferred to be used in initial stages (Gupta et al. 1999). High active recovery of enzymes during ATPS is due to the presence of PEG which causes alteration in the structure of active sites of the enzyme. Researchers have reported the used ATPS for extraction and purification of bromelain from stem and peel of pineapple (Ferreira et al. 2014).

Extraction and purification of bromelain complexed with polyphenol oxidase through ATPS from the pineapple resulted in $228 \%$ active recovery with 4 fold rise in purification (Babu et al. 2008). ATPS has been used to recover bromelain from the peel of 
pineapple and gave $113.54 \%$ and $206 \%$ active recovery with 2.23 and 3.44 purification fold (Ketnawa et al. 2010). In order to optimize the separation of bromelain response surface methodology has been worked in ATPS that yielded $90.33 \%$ enzyme and its purification factor was 2.4 (Navapara et al. 2011). When thermodynamic equilibrium and ATPS were employed together for the purification of bromelain, purification fold came out to be among 25-62 (Ferreira et al. 2011). Moreover, thermoseparation of bromelain resulted in active recovery of $79.5 \%$ with 1.25 purification fold (Rabelo et al. 2004).

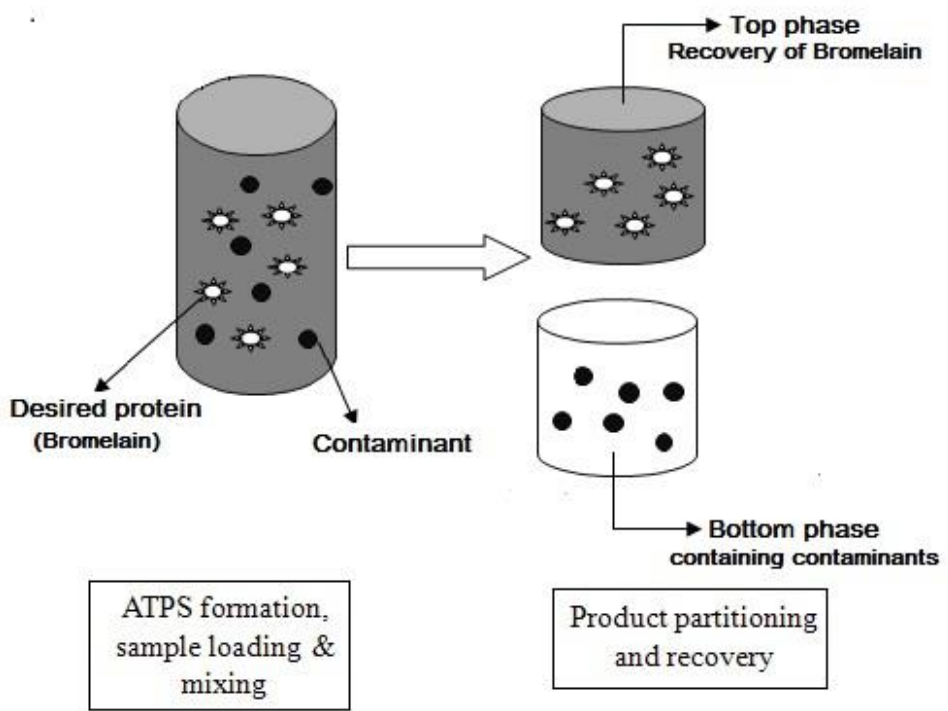

Figure 3 - Extraction and Purification of Bromelain through Aqueous Two Phase System (ATPS).

\section{Chromatographic techniques}

Chromatographic techniques significantly conserve the structure of purified protein (Gautam et al. 2010). Several chromatographic techniques such as ion exchange chromatography (Hung et al. 2002; Arumugam and Ponnusami 2013; Iara et al. 2013; Swaroop and Viswanathan 2013), high-speed counter-current chromatography (HSCCC) (Yin et al. 2011), affinity chromatography, gel filtration chromatography and capillary electrochromatography (Cheng and Huang 2004; Babu et al. 2008; Chen et al. 2008) have been employed for the purification of bromelain. All these techniques possess different specifications thus result in different purification efficiency and recovery (Yin et al. 2011). Amongst these, ion exchange chromatography (IEX) is extensivelyemployed for bromelain separation (Devi and Sowmiya, 2014). Ion exchange chromatography is highly specific, scalable, reliable and a cheap purification method ( $\mathrm{Ng}$ et al. 2009). 10 fold purification of bromelain was achieved using cation exchange chromatography
(Devakate et al. 2009). High-speed counter-current chromatography (HSCCC) has also been used to purify bromelain which generated $3.01 \mathrm{~g}$ bromelain from 5.00g crude extract (Yin et al. 2011).

Immobilized metal affinity membrane (IMAM) has been employed to purify bromelain which resulted in 15.4 fold purification factor with $94.6 \%$ recovery (Nie et al. 2008). 87.4\% active recovery of bromelain was achieved when Poly Acryl Acid (PAA)-bound iron oxide magnetic nanoparticles were used in order to adsorb bromelain from aqueous solution (Cheng and Huang 2004). In the same context, 13 fold purification factor was achieved when bromelain was adsorbed in expanded bed (Silveira et al. 2009). 3.3 fold enhanced purification of bromelain was achieved by the combinations of precipitation and chromatographic techniques (Devakate et al. 2009).

\section{Purification through membrane filtration}

Membrane filtration employs the use of membranes to purify molecules on the basis of size difference. It includes microfiltration and ultrafiltration and is 
considered quite useful for enzymes seclusion as well as concentration (Cassano et al. 2003). Membrane filtration is being used for the isolation and purification of bromelain. Simultaneous use of microfiltration and ultrafiltration in order to separate bromelain from pineapple pulp resulted in active recovery of $85 \%$ (through microfiltration) and 10 fold concentrated bromelain (through ultrafiltration) (Lopes et al. 2009). When microfiltration, ultrafiltration, ammonium sulfate precipitation and ultracentrifugation were employed in a sequence 98\% yield was achieved (Doka et al. 2005).

Membrane filtration in conjugation with other processes results in enhanced purification of bromelain. When stem bromelain was adsorbed on nano- $\mathrm{TiO}_{2}$ and then passes through ultrafilters, 5.3 purification fold and $64.7 \%$ active recovery was achieved (Chao et al. 2009). In a study three methods (Kaolin adsorption, ultrafiltration and tannin precipitation) were performed and compared for bromelain purification. Bromelain with highest proteolytic activity was obtained by ultrafiltration $(\mathrm{Li}$ et al. 2009).

\section{Other methods}

Various other methods have also been worked to separate bromelain and resulted in enhances active recovery and purification fold. Ammonium sulfate precipitation is a cheap and extensively used method for protein purification (Saxena et al. 2007). Ammonium sulfate precipitation resulted in 2.81 purification fold of bromelain (Devakate et al. 2009). In a study ethanolic extraction, isoelectric focusing and ammonium sulfate precipitation were compared for the extraction of bromelain. Amongst these three, ethanolic extract resulted in highest bromelain yield (Silvestre et al. 2011). Likewise, a comparison was also made between ethanol, $\mathrm{PEG}$ and $\left(\mathrm{NH}_{4}\right)_{2} \mathrm{SO}_{4}$ to precipitate bromelain in order to recover it from stem, bark and leaves of pineapple plant. The purification factor achieved after using ethanol was 2.07 fold with $30-70 \%$ recovery. $20-40 \%$ recovery and 4.4 fold purification factor was achieved after precipitation by ammonium sulfate whereas poly (ethylene glycol) failed to precipitate bromelain (Soares et al. 2012). $1400 \mathrm{GDU} / \mathrm{ml}$ proteolytic activity with a protein content of $9.33 \mathrm{mg} / \mathrm{ml}$ was achieved after using homogenization process for bromelain separation (Loh et al. 2005). The use of recyclable mesoporous silica to adsorb bromelain from pineapple juice resulted in 6.2 fold purification with $97.89 \%$ recovery (Arumugam and Ponnusami 2013).

Table 1 - Some modern techniques for the extraction and purification of Bromelain

\begin{tabular}{|c|c|c|c|c|}
\hline $\begin{array}{l}\text { Purification } \\
\text { techniques }\end{array}$ & Types & $\begin{array}{l}\text { Yield } \\
(\%)\end{array}$ & $\begin{array}{l}\text { Purificat } \\
\text { ion } \\
\text { fold/fact } \\
\text { or }\end{array}$ & Reference \\
\hline \multirow{9}{*}{$\begin{array}{l}\text { Aqueous two- } \\
\text { phase system }\end{array}$} & $\begin{array}{l}\mathrm{PEG} / \mathrm{K}_{2} \mathrm{So}_{4} \text { aqueous } \\
\text { system }\end{array}$ & 228 & 4.0 & Babu et al. 2008 \\
\hline & $\begin{array}{lll}\text { PEG/poly(acrylic acid) aqueous } \\
\text { two-phase system }\end{array}$ & $\begin{array}{l}335.2 \\
7\end{array}$ & 25.78 & Novaes et al. 2013 \\
\hline & $\begin{array}{l}\mathrm{PEG} /\left(\mathrm{NH}_{4}\right)_{2} \mathrm{SO}_{4} \text { unconventional } \\
\text { aqueous two-phase system }\end{array}$ & - & 11.80 & Coelho et al. 2013 \\
\hline & $\begin{array}{l}\text { PEG/MgSo4 aqueous two phase } \\
\text { system }\end{array}$ & $\begin{array}{l}113.5 \\
4\end{array}$ & 2.23 & Ketnawa et al. 2010 \\
\hline & $\begin{array}{l}\text { PEG/MgSo4 aqueous two phase } \\
\text { system }\end{array}$ & $\begin{array}{l}108.4 \\
5\end{array}$ & - & Katnawa et al. 2009 \\
\hline & $\begin{array}{l}\text { PEG/MgSo4 aqueous two phase } \\
\text { system }\end{array}$ & 206 & 3.44 & $\begin{array}{l}\text { Ketnawa et al. } \\
2011 \mathrm{a}\end{array}$ \\
\hline & $\begin{array}{l}\text { Block copolymers aqueous two } \\
\text { phase system }\end{array}$ & 79.5 & 1.25 & Rabelo et al. 2004 \\
\hline & $\begin{array}{l}\text { PEG/MgSo4 aqueous two phase } \\
\text { system }\end{array}$ & - & $25-62$ & Ferreira et al. 2011 \\
\hline & $\begin{array}{l}\text { Four various aqueous two phase } \\
\text { system }\end{array}$ & - & - & $\begin{array}{l}\text { Ketnawa et al. } \\
2011 b\end{array}$ \\
\hline
\end{tabular}




\begin{tabular}{|c|c|c|c|c|}
\hline \multirow[t]{3}{*}{ Filtration } & Microfiltration \& ultrafiltration & $\begin{array}{l}85- \\
100\end{array}$ & 10 & Lopes et al. 2009 \\
\hline & $\begin{array}{l}\text { Microfiltration, ammonium sulfate } \\
\text { precipitation, ultracentrifugation }\end{array}$ & 50 & - & Doka et al. 2005 \\
\hline & Nano-TiO 2, ultrafiltration & 64.75 & 5.3 & Chao et al. 2009 \\
\hline \multirow{5}{*}{$\begin{array}{l}\text { Reverse } \\
\text { micellar } \\
\text { systems }\end{array}$} & Reverse micelle systems & 85 & 4 & $\begin{array}{l}\text { Chaurasiya et al. } \\
2015\end{array}$ \\
\hline & Reverse micelle systems & 102 & 5.2 & Hebbar et al. 2008 \\
\hline & Reverse micelle systems & 97.56 & 4.54 & $\begin{array}{l}\text { Hemavathi et al. } \\
2007\end{array}$ \\
\hline & Optimized reverse micelle systems & 89.6 & 2.8 & $\begin{array}{l}\text { Navapara et al. } \\
2011\end{array}$ \\
\hline & $\begin{array}{lll}\begin{array}{l}\text { Affinity-based } \\
\text { system }\end{array} & \text { reverse micelle } \\
\end{array}$ & 185.6 & 12.32 & Kumar et al. 2011 \\
\hline \multirow{4}{*}{$\begin{array}{l}\text { Chromatogra } \\
\text { phy }\end{array}$} & $\begin{array}{l}\text { High speed counter-current } \\
\text { chromatography, reverse } \\
\text { micelle system }\end{array}$ & - & - & Yin et al. 2011 \\
\hline & $\begin{array}{l}\text { Immobilized metal affinity } \\
\text { membrane }\end{array}$ & 94.6 & 15.4 & Nie et al. 2008 \\
\hline & $\begin{array}{lll}\begin{array}{l}\text { Precipitation, ion } \\
\text { chromatography }\end{array} & \text { exchange } \\
\end{array}$ & - & 3.3 & $\begin{array}{l}\text { Devakate et al. } \\
2009\end{array}$ \\
\hline & Cation exchange chromatography & - & 10 & $\begin{array}{l}\text { Nadzirah et al. } \\
2013\end{array}$ \\
\hline
\end{tabular}

\section{APPLICATIONS OF BROMELAIN}

Bromelain has been known for its vast commercial applications. It is being used in food and beverage industries (Neta et al. 2012), in meat tenderization, in cosmetic industries (Orsini 2006) as well as in textile industries (Arshad et al. 2014). Besides its industrial applications, bromelain possess multiple therapeutic actions (Summarized in Table no. 2). Some of its reported actions include inhibition of platelet aggregation, anti-edema (MacKay et al. 2003), antithrombotic and fibrinolytic activity (Errasti et al. 2016), anti-inflammatory action (Brien et al. 2004), anti-tumor action (Dhandayuthapani et al. 2012; Pillai et al. 2013), modulation of cytokines and immunity, skin debridement properties ( $\mathrm{Hu}$ et al. 2011; Rosenberg et al. 2012), enhanced absorption of other drugs (Orsini 2006), mucolytic properties, digestive assistance, enhanced wound healing (Taussig et al. 1988), cardiovascular and circulatory improvement (Kavitha et al. 2013). Some of its therapeutic applications are briefly discussed below.

\section{Anti-inflammatory agent}

Inflammation is the body's attempt of selfprotection which takes into account the discharge of various factors that causes the distention of capillary and enhances their permeability, as a result of which the tissues appear to be inflated and inflamed (Jaber 2002). Mostly NSAIDS (nonsteroidal anti-inflammatory drugs) are prescribed to ward off the classical signs of inflammation (Calor, dolor, rubor and tumor) (Charles et al. 2011), however these drugs severely injures GIT (Gastrointestinal tract) and possess numerous hazardous after effects (Walker et al. 2002) so, as an alternative bromelain has been demonstrated as an anti-inflammatory agent and is in practice for acute inflammation and several related conditions (Hale et al. 2005a). Anti-inflammatory action of bromelain is mediated by retarding the formation of proinflammatory prostaglandins (Graf 2000), reducing the cell surface receptors such as hyaluronan receptor CD44 and plasma fibrinogen levels (Yuan et al. 2006). It also reduces the level of bradykinin, CD4+ T lymphocytes (Manhart et al. 2002) and enhances the activity of serum fibrinolytic thus induces the production of proinflammatory mediators and antiinflammatory prostaglandins as a result of which the distention and permeability of capillaries is reduced (Darshan and Doreswamy 2004; Hale et al. 2005; Tochi et al. 2008). Figure no. 4 displays how bromelain respond to certain mediators of acute inflammation. 


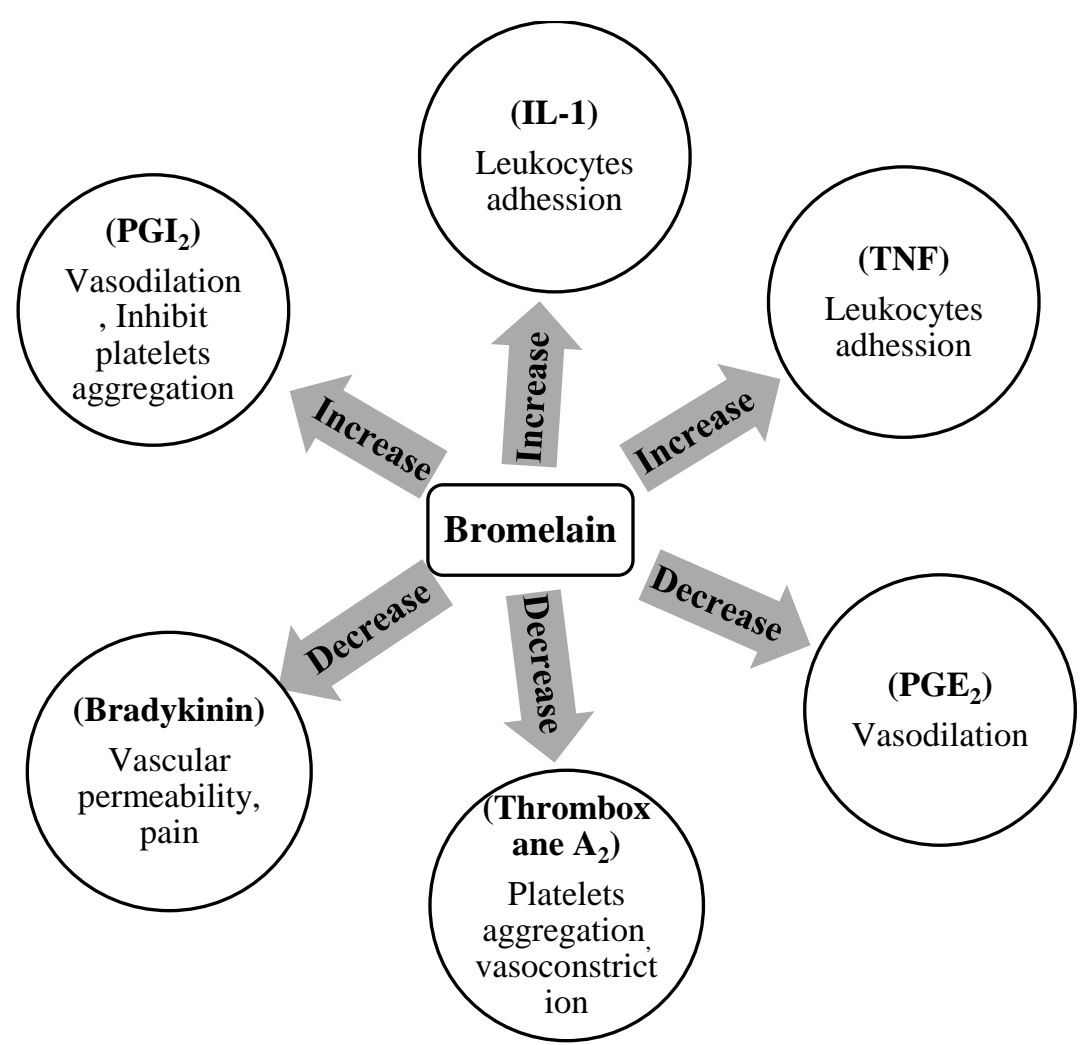

Figure 4: Effect of Bromelain on certain mediators of acute inflammation

\section{Rhinitis and rhinosinusitis}

Rhinosinusitis results in inflammation of nasal cavity and paranasal sinuses (Guo et al. 2006) whereas chronic rhinosinusitis (CRS) is more persistent and long-term inflammation which causes disruption of mucus membranes (Mehdi et al. 2014). Bromelain is an effective mucolytic agent and is being efficiently used in rhinitis, rhinosinusitis as well as in chronic rhinosinusitis (Guo et al. 2006; Buttner et al. 2013). It decreases the formation of pro-inflammatory prostaglandin and reduces swelling in nasal passages (Helms and Miller 2006). Bromelain also decrease mucus production and aids its drainage (Tochi et al. 2008). Beneficial effects of bromelain have been viewed in allergic rhinitis as well where it reduces edema and inflammation (Thor and Kelly 2000).

\section{Arthritis}

NSAIDS are commonly prescribed in arthritis (Henriksson et al. 2014). Bromelain can be used as harmless alternative and researchers have found that bromelain exhibits promising efficacy in arthritis (Osteoarthritis and rheumatoid arthritis) (Pavan et al. 2012). Osteoarthritis, the major form of arthritis, is a leading cause of disability these days. Bromelain is a potent analgesic and displays a direct effect on certain mediators of pain like bradykinin (Brien et al.
2004). Recently it has been found that bromelain, when used in conjugation with other nutraceuticals such as turmeric, results in enhanced efficacy in the treatment of degenerative joint pain diseases (Conrozier et al. 2014).

\section{Colonic inflammation}

Bromelain notably reduce the harshness of colonic inflammation and when taken orally, it significantly reduces the severity of ulcerative colitis (Hale et al. 2005). The chief anti-inflammatory mechanism of bromelain comes out to be proteolytic in nature by which it eradicates cell surface receptors involved in leukocyte defection and activation (Hale et al. 2010). Bromelain also vary the emission of certain chemokines and thus reduces the prevalence and sternness of spontaneous colitis. Due to these researchers regard bromelain as a novel treatment for inflammatory bowel disease (Onkan et al. 2008).

\section{Anti-cancer agent}

In healthy cells, autophagy occurs naturally whereas in tumor cells, this process is deactivated. Cancerous cells metastasize through circulation and transport system to nearby tissues. In many types of cancer p53 gene, which induces apoptosis, is inactivated thus apoptotic cell death is evaded in such cancerous cells (Baez et al. 2007). Researchers have recognized 
numerous anti-cancer mechanisms of bromelain such as switching off the essential gene signal NF-kappaB, suppression of Cox-2 expression, upregulation of p53 and Bax and by initiation of autophagy (Tochi et al. 2008; Bhui et al. 2010). Bromelain exhibits antimetastatic activity, stimulates several caspases and promotes apoptosis. Moreover the use of bromelain in cancer lessens tumor size and results in reduced damage to healthy cells and possesses less after effects as compared to chemotherapy (Bhui et al. 2009; Amini et al. 2016). Bromelain remarkably results in tumor regression for certain cell lines. These include P-388 leukemia, sarcoma (S-37), A431 epidermoid carcinoma, A-375 melanoma, lewis lung cancer (Batkin et al., 1988) and ADC-755 breast cancer (Bhui et al. 2011; Pavan et al. 2012). Furthermore, the use of bromelain in conjugation with chemotherapeutic medicine improves the efficiency of these drugs to certain extent (Pillai et al. 2013; Amini et al. 2014).

\section{Breast Cancer}

Bromelain, a pharmacologically active compound, is a potent anti-tumorigenic agent (Neta et al. 2012). In mammary carcinoma cells bromelain affects MCF-7 cells by slowing down their growth inhibitory response and activate the process of autophagy. Furthermore, bromelain promotes natural cell death (apoptosis) in cancerous cells (Bhui et al. 2010). When taken orally, it also encourages the scarce monocytic cytotoxicity in breast cancer patients (Eckert et al. 1999). Mainly in mammary cancer cells increased dosage of bromelain promotes the process of natural cell death (apoptosis) (Dhandayuthapani et al. 2012).

\section{Epidermoid carcinoma and Melanoma}

The efficacy of bromelain against particular melanoma and epidermoid carcinoma cell lines was checked where bromelain successfully exhibited anti-cancer activity. Bromealin not only minimized their proliferation and reduced the expression of Cox2 gene (Bhui et al. 2012) but also induced apoptosis and suppressed lung metastasis of melanoma cells (Carla et al. 2007). CD44 are the surface proteins present on human leukemia Molt 4/8 cells and are involved in cancer matastasis. Bromelain efficiently reduced the volume of this protein in leukemia and melanoma cells (Harrach et al. 1994).

\section{Inhibitor of thrombus formation}

Platelets aggression and thrombus formation are the leading factors of cardiac discomfort (Bousser 2013).
Akt (a protein kinase) controls numerous cellular processes and is a key player in cardiovascular diseases. It is activated upon phosphorylation (Chaanine and Hajjar 2011). Apoptosis is a chief stimulator of several cardiovascular disorders (Maulik and Das 1994). Upon its activation, Akt inactivates several proapoptotic genes that causes cessation of apoptosis to some extent resulting in cardioprotection (Shiraishi et al. 2004). Bromelain is an effective cardioprotective agent. It possesses antithrombotic and anticoagulant activities and reduces platelet aggregation. It also prohibits the attachment of platelets to endothelial (Metzig et al. 1999). Bromelain results in enhanced phosphorylation of Akt which causes inhibition of apoptotic cell death (Juhasz et al. 2008). Bromelain inhibits clumping of platelets and also put a stop to thrombus formation (Metzag et al. 1999; Bhatacharia 2008). It has the ability to reduce angina and also possess antihypertensive action (Maurer 2001).

\section{Angina Pectoris and Thrombophlebitis}

Bromelain has been effective in the treatment of cardio vascular diseases (Tochi et al.2008). Bromelain promotes the disruption of thrombus, reduces the platelets clumping, blood viscosity and thus reduces the harshness of angina pectoris (Metzik et al. 1999;Maurier 2001) and transient ischemic attack (TIA). Bromelain also helps to reduce the potent risks of thrombophlebitis and aids its treatment (Pavan et al. 2012). Bromelain is also recommended for the treatment of acute thrombophlebitis (Ley et al. 2011).

\section{Burns Debriding agent}

A dry Scab formed on the skin especially after burn is known as eschar which may result in prolonged recovery and also enhance the chance to develop infection (Singer et al. 2010b). Debridement refers to the elimination of dead, damaged, or infected tissue from the site of eschar to improve the healing potential of the remaining healthy tissues (Rosenberg et al. 2012). Debriding the burn eschar surgically is quite challenging and can cause many difficulties (Pavan et al. 2012). On the other hand; enzymatic debridement can minimize such complications and is a safe alternative (Krieger et al. 2012). Amongst these, bromelain is regarded as a potential candidate (Ahle and Hamlet 1987; Maurer 2001). Topical bromelain is being used these days in debriding necrotic tissues ( $\mathrm{Hu}$ et al. 2011; Wu et al. 2012). Bromelain encompasses a fraction of Escharase which is a main debriding agent (Pavan et al. 2012). 
Bromelain is quite specific in its action. It selectively acts upon the effected tissues without harming the normal ones (Rosenberg et al. 2012). Bomelain simplifies the debridement process and offers improved and accelerated healing and quick reepithelialization (Singer et al. 2010a; Hu et al. 2011; Rosenberg et al. 2012). Researchers have found bromelain to be useful in healing post-surgical wounds and aid to lessen their aching and swelling etc (Graf 2000; MacKayand Miller2003).

\section{Asthma}

Asthma refers to the inflammation of air passages resulting in swollen or inflamed airways. Inflammation in asthma is caused mainly due to amplification of eosinophils and $\mathrm{T}$ lymphocytes level in the bronchial mucosa and broncho-alveolar lavage (BAL) fluid (Leblond et al. 2005). Bromelain is an efficient therapeutic agent and is being used successfully in allergic airway disease (AAD) (Secor et al. 2012). Bromelain treats asthma by decreasing the level of total BAL leukocytes (eosinophils and lymphocytes) and cellular infiltrates (Secor et al. 2005) and also notably lessens BAL CD4+, CD8+ T CD4+ and CD25+T cells (Jaber 2002; Darshan and Doreswamy 2004). It also reduces interleukins IL-4, IL-12, IL-13, IL-17 and IFN- $\alpha$ in the serum as well as changes the proportion of CD4+/CD8+ (Secor et al. 2005a; 2007b; 2012c; 2013d).

\section{Blood Coagulation and Fibrinolysis}

Fibrinolysis is a process to prevent fibrin clot from growing and allows the body to clear fragments of clots safely (Maus and Hajjar 2005). Bromelain is regarded as an effective fibrinolytic agent and prevents blood from coagulation (Taussig and Batkin 1988) by exaggerating the transformation of plasminogen to plasma which in turn inhibit fibrin (a protein involved in blood clotting) synthesis (Bhattacharia 2008). It also decreases the proportion of fibrinogen in serum,represses ADP induced platelet aggregation and delay both prothrombin time (PT) and activated partial thromboplastin time (APTT) (Kaur et al. 2014; Errasti et al. 2016). Both extrinsic and intrinsic pathway results in the formation of fibrin ( as shown in Figure no. 5). However bromelain limits its formation by reducing some of the intermediates of clotting cascades (factor $\mathrm{X}$ and prothrombin) and increase fibrinolysis. It also decreases prekallikrein and thus inhibits the generation of bradykinin at the site of inflammation. This results in reduction of pain and edema as well as increases circulation at the site of injury.

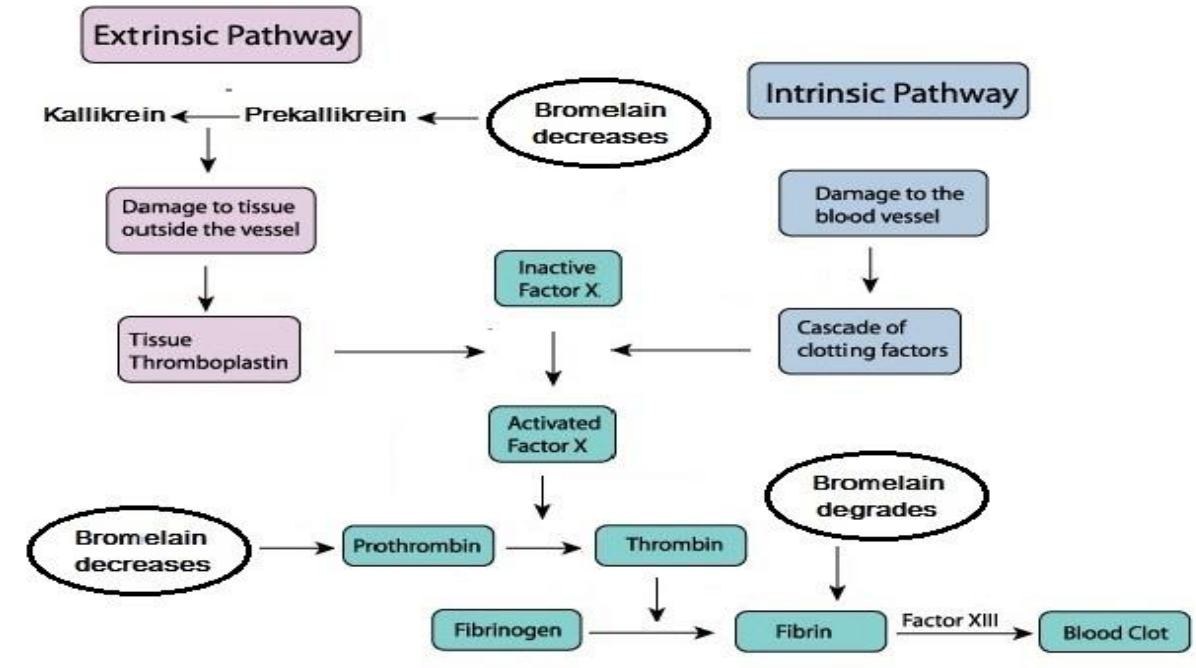

Figure 5: Pathways through which Bromelain inhibits blood clotting.

\section{Dermatological disorders}

Pityriasislichenoideschronica (PLC)

Pityriasislichenoides is a rare cutaneous disorder and is characterized by the development of multiple, scaly, erythematous to brown papules on the trunk and extremities (Someshwar and Udare 2012). Bromelain has been investigated for use in PLC.
After treatment all the victims of PLC were fully recovered with zero side effects which is a virtue of its immuno-modulatory and antiviral trait (Massimiliano et al. 2007).

\section{Scleroderma}


It is a disease characterized by progressive skin hardening and induration that is caused by abnormal growth of connective tissues (Gabrielli et al. 2009).

Table no. 2: Summary of clinical applications of Bromelain.

\begin{tabular}{|c|c|c|c|}
\hline \multirow{7}{*}{$\begin{array}{l}\text { Anti-Inflammatory } \\
\text { agent }\end{array}$} & Disorders & Observed effects & References \\
\hline & Asthma & $\begin{array}{l}\text { Change CD4+ to CD8+ } \mathrm{T} \\
\text { lymphocyte ratio and decreases AAD } \\
\text { (Allergic airway disease). }\end{array}$ & $\begin{array}{l}\text { Jaber et al. 2002; } \\
\underline{\text { Secor et al. } 2008}\end{array}$ \\
\hline & $\begin{array}{l}\text { Chronic } \\
\text { Rhinosinusitis }\end{array}$ & $\begin{array}{l}\text { Retards formation of pro- } \\
\text { inflammatory prostaglandin resulting } \\
\text { in fast recovery. }\end{array}$ & $\begin{array}{l}\text { Bakhshaee et al. } \\
2014\end{array}$ \\
\hline & $\begin{array}{l}\text { Colonic } \\
\text { inflammation }\end{array}$ & $\begin{array}{l}\text { Decreased the occurrence and } \\
\text { severity of spontaneous colitis }\end{array}$ & $\begin{array}{l}\text { Darshan; } \\
\text { Doreswamy } 2004\end{array}$ \\
\hline & Osteoarthritis & $\begin{array}{l}\text { Reduces in joint tenderness, pain and } \\
\text { swelling }\end{array}$ & $\begin{array}{l}\text { Klein 2006; Walker } \\
\text { et al. } 2002\end{array}$ \\
\hline & $\begin{array}{l}\text { Rheumatoid } \\
\text { arthritis }\end{array}$ & Reduce joint stiffness & Maurer 2001 \\
\hline & Soft tissue injuries & Have high wound healing capacity & $\begin{array}{l}\text { Baumann et al. } \\
\text { 2007; Lemay et al. } \\
2004\end{array}$ \\
\hline \multirow{5}{*}{ Anti-tumor agent } & Breast cancer & $\begin{array}{l}\text { Decrease tumor size and cause } \\
\text { apoptosis }\end{array}$ & Baez et al. 2007 \\
\hline & Leukemia & Causes tumor regression & $\begin{array}{l}\text { Maurer 2001;Pavan } \\
\text { et al. } 2012\end{array}$ \\
\hline & Lung carcinoma & $\begin{array}{l}\text { Bromelain possesses antimetastatic } \\
\text { and anticoagulant functions }\end{array}$ & QIMR 2005 \\
\hline & Ovarian cancer & $\begin{array}{l}\text { Decrease tumor growth and invasive } \\
\text { potential }\end{array}$ & Maurer 2001 \\
\hline & Melanoma & $\begin{array}{l}\text { Inhibits nuclear factor-kappab (NF- } \\
\mathrm{kb} \text { ), a protein involved in cancer }\end{array}$ & Kalra et al. 2007 \\
\hline \multirow{4}{*}{$\begin{array}{l}\text { Improvement of } \\
\text { Gastrointestinal } \\
\text { Tract related } \\
\text { discomforts }\end{array}$} & $\begin{array}{l}\text { Postoperative } \\
\text { gastrointestinal } \\
\text { dysmotility (ileus) }\end{array}$ & $\begin{array}{l}\text { Recovers abdominal distention and } \\
\text { increase water content of fecal pellets }\end{array}$ & Wen et al. 2006 \\
\hline & Constipation & Improves stool release in patients & Wen et al.2006 \\
\hline & $\begin{array}{l}\text { Exocrine pancreas } \\
\text { insufficiency }\end{array}$ & Improves digestion & $\begin{array}{l}\text { Knill-Jones et al. } \\
1970\end{array}$ \\
\hline & $\begin{array}{l}\text { Nausea, vomiting, } \\
\text { diarrhea }\end{array}$ & $\begin{array}{l}\text { Neutralizes the effects of } \\
\text { intestinal pathogens that causes NVD }\end{array}$ & Pavan et al. 2012 \\
\hline \multirow{4}{*}{$\begin{array}{l}\text { Inhibition } \\
\text { thrombus } \\
\text { formation }\end{array}$} & Angina pectoris & $\begin{array}{l}\text { Bromelain stops aggregation of } \\
\text { platelets and causes blood thinning }\end{array}$ & $\begin{array}{l}\text { Taussig and Nieper } \\
1979\end{array}$ \\
\hline & $\begin{array}{l}\text { Transient ischemic } \\
\text { attacks }\end{array}$ & Reduces its severity & $\begin{array}{l}\text { Taussig and Nieper } \\
1979\end{array}$ \\
\hline & Thrombophlebitis & Treats thrombophlebitis & Kelly 1996 \\
\hline & Thrombosis & Break down cholesterol plaques & Kelly 1996 \\
\hline \multirow{4}{*}{$\begin{array}{l}\text { Treatment of } \\
\text { Dermatological } \\
\text { disorders }\end{array}$} & Burns/Eschar & $\begin{array}{lll}\begin{array}{l}\text { Topical bromelain } \\
\text { complete debridement }\end{array} & \text { results } & \text { in } \\
\end{array}$ & $\begin{array}{l}\text { Rosenberg } \\
\text { al.2004 }\end{array}$ \\
\hline & Wrinkles & Conditions skin & Reddy et al. 2013 \\
\hline & $\begin{array}{l}\text { Pityriasislichenoide } \\
\text { schronica }\end{array}$ & Complete clinical recovery & $\begin{array}{l}\text { Massimiliano et al. } \\
2007\end{array}$ \\
\hline & Scleroderma & Resolves lesions & Gaby 2006 \\
\hline
\end{tabular}




\section{CONCLUSION}

Bromelain is a concoction of several thiol endopeptidases. It is distinguished as stem bromelain and fruit bromelain depending upon the site of extraction. It is one of the extensively investigated proteolytic enzyme owing to its astonishing applications in various industries. This necessitates to employ a strategy that result in highest purified bromelain in less steps and lowest cost. Use of modernistic approach such as membrane filtration, reverse micellar systems, aqueous two phase extraction and chromatographic techniques have shown promise in this regard.

\section{REFERENCES}

Ahle NW, Hamlet MP. Enzymatic frostbite eschar debridement by bromelain. Ann Emerg Med. 1987; 16(9): 1063-1065.

Amini A, Moghaddam SM, Ehteda A, Morris L. Bromelain and $\mathrm{N}$-acetylcysteine inhibit proliferation and survival of gastrointestinal cancer cells in vitro: significance of combination therapy. $J \quad \operatorname{Exp}$ Clin Cancer Res. 2014; 33(1): 92.

Amini A, Masoumi-Moghaddam S, Morris DL. Bromelain. In: Utility of Bromelain and $\mathrm{N}$ Acetylcysteine in Treatment of Peritoneal Dissemination of Gastrointestinal Mucin-Producing Malignancies. Switzerland: Springer international publishing; 2016. p. 63-80.

Arshad ZIM, Amid A, Yusof F, Jaswir I, Ahmad K, Loke SP. Bromelain: an overview of industrial application and purification strategies. Appl Microbiol Biot. 2014; 98(17): 7283-7297.

Arumugam A, Ponnusami V. Pineapple fruit bromelain recovery using recyclable functionalized ordered mesoporous silica synthesized from sugarcane leaf ash. Braz J Chem Eng. 2013; 30(3): 477-486.

Asenjo JA, Andrews BA. Aqueous two-phase systems for protein separation: a perspective. J Chromatogr A. 2011; 1218(49): 8826-8835.

Babu BR, Rastogi NK, Raghavarao KSMS. Liquid-liquid extraction of bromelain and polyphenol oxidase using aqueous two-phase system. Chem Eng Process. 2008; 47(1): 83-89.

Baez R, Lopes MTP, Salas CE, Hernandez M. In Vivo Antitumoral Activity of Stem Pineapple (Ananascomosus) Bromelain. Planta Med. 2007; 73(13): 1377-1383.

Bakhshaee M, Jabari F, Ghassemi MM, Hourzad S, Deutscher R, Nahid N. The Prevalence of Allergic Rhinitis in Patients with Chronic Rhinosinusitis. Iran J Otorhinolaryngol. 2014; 26(77): 245-249.
Barrett AJ, Rawlings ND, Woessner JF. Handbook of Proteolytic Enzymes. 2. ed. Amsterdam: Elsevier Academic Press, 2004. p. 1051-1071.

Batkin S, Taussig SJ, Szekerezes J. Antimetastatic effect of bromelain with or without its proteolytic and anticoagulant activity. J Cancer Res Clin. 1988; 114(5): 507-508.

Baumann LS. Botanical ingredients in cosmeceuticals. $J$ Drugs Dermatol. 2007; 6(11): 1084-1088.

Bhui K, Prasad S, George J, Shukla Y. Bromelain inhibits COX-2 expression by blocking the activation of MAPK regulated NF-kappa B against skin tumorinitiation triggering mitochondrial death pathway. Cancer Lett. 2009; 282(1): 167-176.

Bhui K, Tyagi S, Prakash B, Shukla Y. Pineapple bromelain induces autophagy, facilitating apoptotic response in mammary carcinoma cells. Biofactors. 2010; 36(6): 474-482.

Bhui K, Tyagi S, Srivastava AK, Singh M, Roy P, Singh R, Shukla Y. Bromelain inhibits nuclear factor kappaB translocation, driving human epidermoid carcinoma A431 and melanoma A375 cells through G(2)/M arrest to apoptosis. Mol Carcinogen. 2011; 51(3): 231-243.

Bousser MG. Platelets, atherothrombosis, antiplatelet drugs and cerebral ischemia. B Acad Nat Med. 2013; 197(2): 389-394.

Buttner L, Achilles N, Bohm M, Hosseini KS, Mosges R. Efficacy and tolerability of bromelain in patients with chronic rhinosinusitis--a pilot study. B-ENT. 2013; 9(3): 217-225.

Cassano A, Drioli E, Galalaverna G, Marchelli R, Silvestro $\mathrm{R}$, Cagnasso P. Clarification and concentration of citrus and carrot juices by integrated membrane processes. J Food Eng. 2003; 57(1): 153-163.

Chaanine AH, Hajjar RJ. AKT signalling in the failing heart. Eur J Heart Fail. 2011; 13(8): 825-829.

Charles NS, Ward PA, Gilroy DW. Fundamentals of Inflammation. Yale J Biol Med. 2011; 84(1): 64-65.

Chaurasiya RS, Sakhare PZ, Bhaskar N, Hebbar HU. Efficacy of reverse micellar extracted fruit bromelain in meat tenderization. $J$ Food Sci Technol. 2015; 52(6): 3870-3880.

Chen D, Huang S. Fast separation of bromelain by polyacrylic acid-bound iron oxide magnetic nanoparticles. Process Biochem. 2004; 39(1): $2207-$ 2211.

Chen T, Su S, Nie H, Zhu L. Display: Design and selection of functional binding peptides ligands application for isolation of bromelain using affinity chromatography. J Biotechnol. 2008; 136(1): 620-632.

Coelho DF, Silveira E, Pessoa JA, Tambourgi EB. Bromelain purification through unconventional aqueous two-phase system (PEG/ammonium sulphate). Bioprocess Biosyst Eng. 2013; 36(2): 185192.

Conrozier T, Mathieu P, Bonjean M, Marc JF, Renevier JL, Balblanc JC. A complex of three natural anti- 
inflammatory agents provides relief of osteoarthritis pain. Altern Ther Health Med.2014; 20(1): 32-37.

Corzo CA, Krzysztof, Waliszewski KN, Welti-Chanes J. Pineapple fruit bromelain affinity to different protein substrates. Food Chem. 2011; 133(3): 631-635.

Darshan S, Doreswamy R. Patented anti- inflammatory plant drug development from traditional medicine. Phytother Res. 2004; 18(5): 343-357.

De Lencastre NLC, Jozala AF, Lopes AM, De Carvalho SEV, Mazzola PG, Pessoa A. Stability, purification, and applications of bromelain: A review. Biotechnol Prog. 2016; 32(1): 5-13.

Dhandayuthapani S, Perez HD, Paroulek A, Chinnakkannu P, Kandalam U, Jaffe M, Rathinavelu A. Bromelain-induced apoptosis in GI-101A breast cancer cells. J Med Food. 2012; 15(4): 344-349.

Dhaneshwar AD, Chaurasiya RS, Hebbar HU. Process optimization for reverse micellar extraction of stem bromelain with a focus on back extraction. Biotechnol Prog.2014; 30(4): 845-855.

Doko B, Bassani V, Casadebaig J, Cavailles L, Jacob M. Preparation of proteolytic enzyme extracts from Ananascomosus L. Merr. fruit juice using semi permeable membrane, ammonium sulfate extraction, centrifugation and freeze-drying processes. $J$ Immunopharmaco. 2005; 4(5): 783-795.

Eckert K, Grabowska E, Stange R, Schneider U, Eschmann K, Maurer HR. Effects of oral bromelain administration on the impaired immunocytotoxicity of mononuclear cells from mammary tumor patients. Oncol Rep. 1999; 6(6): 1191-1199.

Errasti ME, Prospitti A, Viana CA, Gonzalez MM, Ramos MV, Rotelli AE, Caffini NO. Effects on fibrinogen, fibrin, and blood coagulation of proteolytic extracts from fruits of Pseudananasmacrodontes, Bromeliabalansae, and B. hieronymi (Bromeliaceae) in comparison with bromelain. Blood Coagul Fibrinolysis. Epub 2016, Feb 15.

Ferreira FJ, Santana JCC, Tambourgi EB. The effect of $\mathrm{pH}$ on bromelain partition from Ananascomosus by PEG4000/Phosphate ATPS. Braz Arch Biol Technol. 2011; 54(1): 125-132.

Fileti AM, Fischer GA, Tambourgi EB. Optimizing bromelain extraction by reversed micelles from pineapple fruit. Chem Eng Transc. 2007; 11(1): 989-994.

Fileti AMF, Fischer GA, Santana JCC, Tambourgi EB. Batch and continuous extraction of bromelain enzyme by reversed micelles. Braz Arch Biol Technol. 2009; 52(5): 1225 -1234.

Gabrielli A, Avvedimento EV, Krieg T. Scleroderma. New Engl J Med. 2009; 360(19): 1989-2003.

Gaby AR. Natural remedies for scleroderma. Altern Med Rev.2006; 11(3): 188-195.

Gautam SS, Mishra SK, Dash V, Goyal AK, Rath G. Comparative study of extraction, purification and estimation of bromelain from stem and fruit of pineapple plant. Thai J Pharm. 2010; 34(1): 67-76.
Graf J. Herbal Anti-Inflammatory Agents for Skin Disease. Skin Therapy Lett. 2000; 5(4): 3-5.

Grzonka Z, Kasprzykowski F, and Wiczk W. Cysteine proteases. In: Polaina, J and P. MacCabe. Industrial Enzymes, NY, USA: Springer; 2007.p. 181-195.

Guo R, Canter PH, Ernst E. Herbal medicines for the treatment of rhinosinusitis: a systematic review, Otolaryn. Head Neck Surg. 2006; 135(4): 496-506.

Gupta R, Bradoo S, Saxena RK. Aqueous two-phase systems: an attractive technology for downstream processing of biomolecules. Curr Sci. 1999; 77(4): 520-523.

Gupta YR, Gupta N, Rathi P. Bacterial lipases: an overview of production, purification and biochemical properties. Appl Microbiol Biotechnol. 2004; 64(6): 763-781.

Hale LP, Greer PK, Trinh CT, James CL. Proteinase activity and stability of natural bromelain preparations. Int Immunopharmacol. 2005; 5(4): 783-793.

Hale LP, Greer PK, Trinh CT, Gottfried MR. Treatment with oral bromelain decreases colonic inflammation in the IL-10-deficient murine model of inflammatory bowel disease. Clin Immunol. 2005; 116(2): 135-142.

Hale LP, Chichlowski M, Trinh CT, Greer PK. Dietary supplementation with fresh pineapple juice decreases inflammation and colonic neoplasia in IL-10-deficient mice with colitis. Inflamm Bowel Dis.2010; 16(12): 2012-2021.

Harrach T, Eckert K, Maurer HR, Machleidt I, Machleidt W, Nuck R. Isolation and characterization of two forms of an acidic bromelain stem proteinase. J Protein Chem. 1998; 17(4): 351-361.

Harrach T, Gebauer F, Eckert K, Kunze R, Maurer H. Bromelain proteinases modulate the $\mathrm{cd} 44$ expression on human molt-4/8 leukemia and sk-mel-28 melanoma-cells in-vitro. Int J Oncol.1994; 5(3): 485488.

Hebbar HU, Hemavathi AB, Sumana B, Raghavarao KSMS. Reverse micellar extraction of bromelain from pineapple (ananascomosus 1. merryl) waste: scale-up, reverse micelles characterization and mass transfer studies. Sep Sci Technol. 2011; 46(10): 1656-1664.

Hebbar HU, Sumana B, Hemavathi AB, Raghavarao KSMS. Separation and Purification of Bromelain by Reverse Micellar Extraction Coupled Ultrafiltration and Comparative Studies with Other Methods. Food Bioprocess Technol.2012; 5(3): 1010-1018.

Hebbar HU, Sumana B, Raghavarao KSMS. Use of reverse micellar systems for the extraction and purification of bromelain from pineapple wastes. Bioresource Technol. 2008; 99(1): 4896-4902.

Helms S, Miller A. Natural treatment of chronic rhinosinusitis.Altern Med Rev. 2006; 11(3): 196-207.

Hemavathi AB, Hebbar HU, Raghavarao KSMS. Reverse micellar extraction of bromelain from Ananascomosus L. Merryl. J Chem Tech Biotech. 2007; 82(11): 985992. 
Henriksson K, From J, Stratelis G. Patient-reported adherence to coprescribed proton pump inhibitor gastroprotection in osteoarthritis, rheumatoid arthritis, and ankylosing spondylitis patients using nonsteroidal anti-inflammatory drugs. Patient Prefer Adherence. 2014; 8(1): 1611-1617.

Hossain MM, Lee SI, Kim IH. Effects of bromelain supplementation on growth performance, nutrient digestibility, blood profiles, faecal microbial shedding, faecal score and faecal noxious gas emission in weanling pigs. Veterinarni Medicina. 2015; 60(10): 544-552.

Hu W, Wang AM, Wu SY, Zhang B, Liu S, Gou YB, Wang JM. Debriding effect of bromelain on firearm wounds in pigs. J Trauma. 2011; 71(4): 966-972.

Hung TH, Chang YM, Sung HY, Chang CT. Purification and characterization of hydrolase with chitinase and chitosanase activity from commercial stem bromelain. J Agric Food Chem. 2002; 50(16): 4666-4673.

Jaber R. Respiratory and allergic diseases: From upper respiratory tract infections to asthma. Prim Care. 2002; 29(2): 231-261.

Illanes A. Enzyme Production. In: Enzyme Biocatalysis. Brazil: Springer Science and Business Media V.B. 2008; p. 57-106.

Johansson HO, Feitosa E, Pessoa A. Phase Diagrams of the Aqueous Two-Phase Systems of Poly (ethylene glycol)/Sodium Polyacrylate/Salts. Polymers. 2011; 3(1): 587-601.

Juhasz B, Thirunavukkarasu M, Pant R, Zhan L, Penumathsa SV, Secor ER, Srivastava S,Raychaudhuri U, Menon VP, Otani H, Thrall RS, Maulik N. Bromelain induces cardioprotection against ischemiareperfusion injury through Akt/FOXO pathway in rat myocardium. Am J Physiol-Heart C. 2008; 294(3): 1365-1370.

Jutamongkon R, Charoenrein S. Effect of Temperature on the Stability of Fruit Bromelain from Smooth Cayenne Pineapple. Kasetsart J Nat Sci. 2010; 44(5): 943-948.

Kaur H, Corscadden K, Lott C, Elbatarny HS, Othman M. Bromelain has paradoxical effects on blood coagulability: a study using thromboelastography.Blood Coagul Fibrinolysis. Epub 2014 Dec 16.

Ketnawa S, Chaiwut P, Rawdkuen S. Aqueous Two-phase Extraction of Bromelain from Pineapple Peels ('PhuLae' cultv.) and Its Biochemical Properties. Food Sci Biotechnol. 2011; 20(5): 1219-1226.

Ketnawa S, Rawdkuen S, Chaiwut P. Two phase partitioning and collagen hydrolysis of bromelain from pineapple peel Nang Laecultivar. J Biochem Eng. 2010; 52(2-3): 205-211.

Ketnawa S, Sai-Ut S, Theppakorn T, Chaiwut P, Rawdkuen S. 2009. Partitioning of bromelain from pineapple peel (Nang Laecultv.) by aqueous two phase system. As J Food Ag-Ind. 2009; 2(4): 457-468.
Krieger Y, Bogdanov-Berezovsky A, Gurfinkel R, Silberstein E, Sagi A, Rosenberg L. Efficacy of enzymatic debridement of deeply burned hands. Burns. 2012; 38(1): 108-112.

Kumar S, Hemavathi AB, Hebbar HU. Affinity based reverse micellar extraction and purification of bromelain from pineapple (Ananascomosus L. Merryl) waste. Process Biochem. 2011; 46(5): 1216-1220.

Larocca M, Rossano R, Santamaria M, Riccio P. Analysis of pineapple [Ananascomosus (L.) Merr.] fruit proteinases by 2-D zymography and direct identification of the major zymographic spots by mass spectrometry. Food Chem. 2010; 123(1): 1334-1342.

Lee KL, Chong CC. The use of Reverse Micelles in Downstream Processing of Biotechnological Products. 2011.

Ley CM, Tsiami A, Ni Q, Robinson N. A review of the use of bromelain in cardiovascular diseases. J Chin Integr Med. 2011; 9(7): 702-710.

Lightfoot EN. 1990. Protein purification from molecular mechanisms to large scale processes. In: Ladisch MR, Willson RC, Painton CC, Builder SE. Separation in biotechnology-the key role of adsorptive separations. ACS Publications; 1990. p. 35-51.

Lopes FLG, Junior JBS, Souza RR, Ehrhardt DD, Santana JCC, Tambourgi EB. Concentration by Membrane Separation Processes of a Medicinal Product Obtained from Pineapple Pulp. Braz Arch Biol Technol. 2009; 52 (2): 457-464.

MacKay ND, Miller AL. Nutritional Support for Wound Healing. Altern Med Rev. 2003; 8(4): 359-377.

Manhart N, Akomeah R, Bergmeister H, Spittler A, Ploner M, Roth E. Administration of proteolytic enzymes bromelain and trypsin diminish the number of CD4+ cells and interferon-gamma response in Peyer's patches and spleen in endotoxemicbalb/c mice. Cell Immunol. 2002; 215(2): 113-119.

Marshall JS, Golden KD. Characterization of Bromelain from Morindacitrifolia (Noni). J Sci Res. 2012; 4 (2): 445-456.

Massimiliano R, Pietro R, Paolo S, Sara P, Michele F. Role of bromelain in the treatment of patients with pityriasislichenoideschronica. $J$ Dermatolog Treat. 2007; 18(4): 219-222.

Maulik, N, Das DK. Apoptosis, heart failure, ischemic heart disease. Heart Fail Rev. 1994; 4(1): 1-9.

Maurer HR. Bromelain: biochemistry, pharmacology and medical use. Cell Mol Life Sci. 2001; 58(9): 12341245.

Metzig C, Grabowska E, Eckert K, Rehse K, Maurer HR. Bromelain proteases reduce human platelet aggregation in vitro, adhesion to bovine endothelial cells and thrombus formation in rat vessels in vivo. In Vivo. 1999; 13(1): 7-12.

Nadzirah KZ, Zainal S, Noriham A, Normah I. Efficacy of selected purification techniques for bromelain. IFRJ. 2013; 20(1): 43-46. 
Navapara RD, Avhad DN, Rathod VK. Application of Response Surface Methodology for Optimization of Bromelain Extraction in Aqueous Two-Phase System. Sep. Sci. Technol. 2011; 46(11): 1838-1847.

Neta JLV, DaSilva LA, Lima AA, Santana JC, Leite NS, Ruzene DS, SilvaDP,DeSouza RR. Bromelain Enzyme from Pineapple: In Vitro Activity Study under Different Micropropagation Conditions. Appl Biochem Biotechnol. 2012; 168(2): 234-246.

Ng PK, He J, Synder MK. Separation of proteins mixtures using $\mathrm{PH}$-gradient cation exchange chromatography. $J$ Chromatogr A. 2009; 1216(9): 1372-1376.

Nie H, Li S, Zhou Y, Chen T, He Z, Su S, Zhang H, Xue Y, Zhu L. Purification of bromelain using immobilized metal affinity membranes. J Biotechnol. 2008; 136: 620-632.

Novaes LC, Ebinuma VC, Mazzola PG, Pessoa A. Polymer-based alternative method to extract bromelain from pineapple peel waste. Biotechnol Appl Biochem. 2013; 60(5): 527-535.

Onken JE, Greer PK, Calingaert B, Hale LP. Bromelain Treatment Decreases Secretion of Pro-Inflammatory Cytokines and Chemokines by Colon Biopsies. In Vitro ClinImmunol. 2008; 126(3): 345-352.

Orsini RA. Bromelain. Plast Reconstr Surg.2006; 118(7): 1640-1644.

Pavan R, Jain S, Shraddha, Kumar A. Properties and Therapeutic Application of Bromelain: A Review. Biotechnol Res Int. 2012; 2012(1): 1-6.

Pillai K, Akhter J, Chua TC, Morris DL. Anticancer Property of Bromelain with Therapeutic Potential in Malignant Peritoneal Mesothelioma. Cancer Invest. 2013; 31(4): 241-250.

Rabelo APB, Tambourgi EB, Pessoa A. Bromelain partioning in twophase aqueous systems containing PEO-PPO-PEO block copolymers. J Chromatogr B. 2004; 807(1): 61-68.

Reddy KK, Grossman L, Rogers GS. Common complementary and alternative therapies with potential use in dermatologic surgery: Risks and benefits. $J$ Am AcadDermatol. 2013; 68(4): 127-135.

Rosenberg L, Krieger Y, Silberstein E, Arnon O, Sinelnikov IA, Bogdanov-Berezovsky A, Singer AJ. Selectivity of a bromelain based enzymatic debridement agent: a porcine study. Burns. 2012; 38(7): 1035-1040.

Rowan AD, Buttle DJ, Barrett AJ. The cysteine proteinases of the pineapple plant. Biochem J. 1990; 266(3): 869-875.

Saxena L, Iyer BK, Ananthanarayan L. Three phase partitioning as a novel method for purification of ragi (Eleusinecoracana) bifunctional amylase/ protease inhibitor. Process Biochem.2007; 42(3): 491-495.

Secor ER, Carson WF, Cloutier MM, Guernsey LA, Schramm CM, Wu CA, Thrall RS. Bromelain exerts anti-inflammatory effects in an ovalbumin-induced murine model of allergic airway disease. Cell Immunol. 2005; 237(1): 68-75.
Secor ER, Shah SJ, Guernsey LA, Schramm CM, Thrall RS. Bromelain limits airway inflammation in an ovalbumin-induced murine model of established asthma. Altern Ther Health M. 2012; 18(5): 9-17.

Secor ER, Szczepanek SM, Castater CA, Adami AJ, Matson AP, Rafti ET, Guernsey L, Natarajan P, McNamara JT, Schramm CM, Thrall RS, Silbart LK. Bromelain Inhibits Allergic Sensitization and Murine Asthma via Modulation of Dendritic Cells. Evid Based Complement Alternat Med. 2013; 2013(1): 1-9.

Secor ER., Carson WF, Singh A, Pensa M, Guernsey LA, Schramm CM, Thrall RS. Oral Bromelain Attenuates Inflammation in an Ovalbumin-induced Murine Model of Asthma. Evid Based Complement Alternat Med. 2008; 5(1): 61-69.

Shiraishi I, Melendez J, Ahn Y, Skavdahl M, Murphy E, Welch S, Schaefer E, Walsh K, Rosenzweig A, Torella D, Nurzynska D, Kajstura J, Leri A, Sussman P. Nuclear targeting of Akt enhances kinase activity and survival of cardiomyocytes. Circ Res.2004; 94(7): 884891.

Silvestre MPC, Carreira RL, Silva MR, Corgosinho FC, Monteiro MRP, Morais HA. Effect of $\mathrm{pH}$ and temperature on the activity of enzymatic extracts from pineapple peel. Food Bioprocess Technol. 2012; 5(5): 1824-1831.

Singer AJ, McClain SA, Taira BR, Rooney J, Steinhauff N, Rosenberg L. Rapid and selective enzymatic debridement of porcine comb burns with bromelain-derived Debrase: acute-phase preservation of noninjured tissue and zone of stasis. $J$ Burn Care Res.2010; 31(2): 304-309.

Singer AJ, Taira BR, Anderson R, McClain SA, Rosenberg L. The effects of rapid enzymatic debridement of deep partial-thickness burns with Debrase on wound reepithelialization in swine. $J$ Burn Care Res.2010; 31(5): 795-802.

Smith-Marshall J. Golden KD. Characterization of Bromelain from Morindacitrifolia (Noni). J Sci Res. 2012; 4(2): 445-456.

Soares PAG, Vaz AFM, Correia MTS, Pessoa A Maria G, Cunha C. Purification of bromelain from pineapple wastes by ethanol precipitation. Sep Purif Technol. 2012; 98(2138): 389-395.

Someshwar S, Udare S. Pityriasislichenoides. Indian Pediatr.2012; 49(11): 936-941.

Spir LG, Ataide JA, Novaes LC, Moriel P, Mazzola PG, Gurpilhares D, Silveira E, Pessoa A, Tambourgi EB. Application of an aqueous two-phase micellar system to extract bromelain from pineapple (Ananascomosus) peel waste and analysis of bromelain stability in cosmetic formulations. Biotechnol Prog.2015; 31(4): 937-945.

Swaroop G, Viswanathan G. Isolation and Characterization of Bromelain (BML) Proteases from Ananascomosus an asset to Cancer Chemotherapy. IJCPT. 2013; 1(2): 82-90. 
Taussig SJ, Batkin S. Bromelain, the enzyme complex of pineapple (Ananascomosus) and its clinical application. An update. Ethno pharmacol. 1988; 22(2): 191-203.

Taussig SJ, Szekerczes J, Batkin S. Inhibition of tumour growth in vitro by bromelain, an extract of the pineapple plant (Ananascomosus). Planta Med. 1985; 51(6): 538-539.

Tochi BN, Wang Z, Xu SY, Zhang W. Therapeutic Application of Pineapple Protease (Bromelain): A Review. Pakistan J Nutrition. 2008; 7 (4): 513-520.

Upadhyay A, Lama JP, Tawata S. Utilization of Pineapple Waste: A Review. J Food Sci Technol. 2010; 6(1): 1018.

Walker AF, Bundy R, Hicks SM, Middleton RW. Bromelain reduces mild acute knee pain and improves well-being in a dose-dependent fashion in an open study of otherwise healthy adults. Phytomedicine. 2002; 9(8): 681-686.
Wu SY, Hu W, Zhang B, Liu S, Wang JM, Wang AM. Bromelain ameliorates the wound microenvironment and improves the healing of firearm wounds. J Surg Res. 2012; 176(2): 503-509.

Xue Y, Wu C, Branford-White CJ, Ning X, Nie H, Zhu L. Chemical modification of stem bromelain with anhydride groups to enhance its stability and catalytic activity. J MolCatal. B-Enzym. 2010; 63(3): 188-193.

Yin L, Sun CK, Han X, Xu L, Xu Y, Qi Y, Peng J. Preparative purification of bromelain (EC 3.4.22.33) from pineapple fruit by high-speed counter-current chromatography using a reverse-micelle solvent system. Food Chem. 2011; 129(3): 925-932.

Yuan G, Wahlqvist ML, He G, Yang M, Li D. Natural products and anti-inflammatory activity. Asia Pac J ClinNutr. 2006; 15(2): 143-152.

Received: January 06, 2016; Accepted: April 07, 2016. 